\title{
Environmental effects due to the technological processes of lime production
}

\author{
${ }^{1}$ D Cîrţînă, ${ }^{2}$ A Tudorache \\ ${ }^{1}$ Faculty of Medical and Behavioral Sciences, "Constantin Brâncusi” University of Targu \\ Jiu, Romania \\ ${ }^{2}$ Faculty of Engineering, "Constantin Brâncusi” University of Targu Jiu, Romania \\ E-mail: danielacirtina@gmail.com
}

\begin{abstract}
The paper presents the way of obtaining lime, the technological processes adopted and the resulting products. The process of obtaining lime has effects on the environment, affecting through the emissions of pollutants, as well as the quality of air, water and soil. That is why this process of obtaining lime must comply with the regulations in force to ensure a balance between the industrial environment and the environment. At the same time, it is important to know the sources of pollution, but also the measures for the protection of the quality of the environmental factors, so as to ensure a control of the emissions resulting from the lime industry and a low level of pollution, without significant effects on the environment.
\end{abstract}

Keyword: environment, lime, technological processes

\section{Introduction}

In a lime factory there are several technological processes that are carried out for obtaining lime, namely: obtaining lumps lime in vertical ovens; obtaining the ground lime; obtaining hydrated lime; production of lime in the vertical oven, regenerating with 3 tanks in parallel flow type Maerz[1]; technological process for obtaining lumps lime with granulation $(20-50) \mathrm{mm}$.

\section{The technological process of obtaining lumps lime}

The technological process for making lumps lime comprises the following stages:

- unloading and storing limestone in 4 silos with a storage capacity of 600 tons each;

- burning of limestone in 4 vertical type Bicaz[2] ovens;

- lime storage and shipping.

The raw material used to make the lumps lime is the limestone that burns in the furnaces, using as a source of energy the natural gas. The limestone deposited in the silo is sorted on a sieve with bars and then transported with the aid of the tape system to the furnace feed bunkers, located at its top.

In the area of the bar sorter there is a dust filter and at each furnace a filter that dusts the flue gases from the oven to the basket.

Obtaining the finished product, lumps lime, in vertical Bicaz [2] type ovens takes place in three stages, in the three zones of the oven:

- at the top - preheating of the raw material; 
- in the central area - calcination - decarbonation of limestone at $1200-1300^{0}$ Celsius;

- at the bottom - cooling of the lime.

Two minifilters are provided for the clearing of the transport system for lumps lime.

Lime extraction is done through 4 extraction holes using an oscillating gutter and is stored in 4 siloes.

Filters that extract gas from the furnaces are also common with the lime extraction area [10].

\section{1) Obtaining the ground lime}

The lumps lime is extracted through a mechanical extraction system mounted under the silo and is taken by a conveyor belt and transported to the mill with hammers. The mill is equipped with a bag filter for dust removal.

In the hammer mill, which has a feed rate of $15 \mathrm{t} / \mathrm{h}$, the crushing of the lumps industrial lime takes place at a granulation of $(0-15) \mathrm{mm}$.

The crushed lime (lime splint) from the hammer mill is taken over by an inclined conveyor belt and transported to the 80-ton buffer silo. This silo is equipped with a filter with dust bags.

In order to obtain the milled lime for BCA[3] - the granulated lime is extracted from the silo of 80 tons, by means of a bar and a dosing tape and is introduced in the single-chamber ball mill type Liasa[2]. After grinding in the ball mill, the ground lime is transported by means of a screw system elevator - rubber band, in the dynamic separator with cyclones. In the separator the pneumatic separation of the ground lime takes place:

- the fine fraction will reach the cyclones and from there it will be guided in the collecting screws and then in the elevator with cups on the chain that will lift it and will unload it gravitationally in the storage and delivery silo.

- the coarse fraction will reach the central cone of the separator and from here it will be recycled into the ball mill by means of a screw. The mill for milling and the dynamic separator are equipped with filter bag.

\section{2) Obtaining hydrated lime}

The raw material used to obtain hydrated lime is lumps lime. The lumps lime is ground in the hammer mill up to $0-15 \mathrm{~mm}$ granulation and stored in the granulated lime silo from where it is introduced into the three-step hydrator.

Hydration of lime is a strongly exothermic reaction that generates around $1140 \mathrm{KJ} / \mathrm{Kg} \mathrm{CaO}[10]$. The hydrated lime obtained is discharged into the elevator and from here into a dynamic separator which results in two fractions: the fine fraction that is stored in the hydrated lime silo and the coarse fraction that is ground in the ball mill and is reintroduced into the gray elevator after which the cycle resumes.

The delivery of hydrated lime is done in bags, using the packing machine which is equipped with a dust filter, or bulk for which there is the loading facility being transported in tanks.

Hammer mill, granulated lime silo, hydration plant, hydrated lime silo, ball mill are provided with a dust filter.

\section{3) Lime production in the vertical furnace, regenerating with 3 tanks in parallel flow type Maerz}

The furnace is made of 3 rectangular shaped tanks arranged at 120 degrees, connected to each other at the lower limit of the combustion zone through gas circulation channels. The oven capacity is 300 tons lime / day. The oven has a non-stationary, cyclical operation, each tank passing successively through 3 periods of 10-7 minutes each, one burning and two regenerating, separated by short inversions of approx. 1 minute, in which the change of the position of the valves, the feeding with limestone and the unloading of lime are carried out.

The extraction of lime is done all the time of the oven's operation with the help of the extraction masses, whose operation is controlled[5]. The extracted lime is collected in a bunker, and from here it is guided by opening the sluices in the drainage bunker and transported according to quality and necessities. 
The furnace is fed from the storage silos, the limestone is extracted by means of an oscillating gutter and transported with conveyor belts to a sorting system provided with two screens where the separation of the limestone takes place in the two granulometric fractions necessary to supply the furnace and the elimination of the lot.

The sort $<20 \mathrm{~mm}$ is stored by means of a bucket elevator, in a metal bunker, from here it is taken with self-tilting machines, weighed and stored for later processing in order to obtain the limestone filler or it can be marketed as such.

After sorting, the two particle size fractions are sent through a conveyor system with tape to an intermediate silo near the oven. The silo is divided into two compartments: one of 60 tons for the sort (40-70) $\mathrm{mm}$ and one of 20 tons for the fraction (20-40) $\mathrm{mm}$. Each compartment is provided with a vibrating extractor that extracts the amount of limestone programmed in the weighing bunker. When the programmed quantity has been reached, the extractor shutdown and the closing flap of the weighing bunker are automatically activated, the limestone being discharged. The skip transports the limestone in a bunker with three holes, with a capacity of 6 tons, located at the top of the oven. The three-way bunker is provided with three hydraulically operated discharge valves and is connected to the three tanks through three discharge funnels. From the bunker during the inversion period the limestone is unloaded in a tank by opening the corresponding flap the other two remain closed.

To burn the limestone, the material goes into the furnace, where the decarbonation of the limestone takes place, until it reaches the final product, lumps lime[8]. The combustion air is introduced into the tank in which the combustion takes place on the upper part, equilibrating with the material.

The gas is introduced into the combustion zone of the tank through a combustion system composed of three parts:

1) the gas installation itself consisting of: electrically operated solenoid valve, three electropneumatically operated valves, a safety valve, two bi-pass valves. The valves are operated with pneumatic air at a pressure of 6 bar;

2) the automation installation that serves the gas installation electronically controlled by the automatic oven program;

3) gas spears made of refractory stainless steel. In each tank there are 20 vertical, parallel and equidistant spears arranged symmetrically on the surface of the vessel at an appropriate distance from the masonry. The lances are fitted with nozzles with diameters between $5-8 \mathrm{~mm}$, depending on the gas pressure.

The required gas pressure is 3,5 bar and the gas consumption is about $1400 \mathrm{mc} /$ hour[9].

The cooling air circulates in the cooling zone in counter current with the lime, after which it passes along with the flue gases coming from the upper part through the connecting channels in the other two tanks of the oven.

The required cooling and combustion air for the lime furnace is provided by a blower station. There are eight blowers: five of combustion, two of cooling and one common reserve. For adjusting the cooling and combustion air flows according to the requirements of the combustion process, two blowers are variable speed. The furnace is provided with a hydraulic installation that ensures, by means of pistons, the actuation: the shut-off valves, the discharge bumpers, the double combustion air flaps, the feelers, the extraction tables, the detent flaps, the locks. The pistons in turn are controlled with the help of electrodistributors depending on the operating conditions imposed. The hydraulic system working system is in open circuit, with manual oil pressure adjustment. It consists of three groups of elements: the pumping group consisting of two pumps and the oil tank; the furnace installation that includes the blocks with distribution-adjustment devices and the hydraulic cylinders for operating the mechanisms; pipes that ensure the connection between the pumping station, the blocks with the distribution-adjustment devices and the actuating cylinders.

On the furnace there are mounted measuring and control devices: on the combustion air pipe and on the cooling pipe are installed - diaphragms for flow measurement and pressure gauges; on each fan there is a pressure measuring device; on each thermocouple tank for measuring the flue gas 
temperature; for measuring the lime temperature there are two thermocouples in the area of the extraction tables; in the connecting channels the gas pressure and the gas temperature are measured.

For measuring the level of limestone in the oven is mounted on each tank a device that consists of a shaft with two chain wheels, the shaft being mounted on bearings with bearings. One end of the chain is fixed to a wheel and the other is attached to the rod of a hydraulic control cylinder. The other wheel is provided with a chain with welded spindles, one end of the chain is fixed to the wheel and to the other the weight of the chain is stretched and actuated. On the axis of the device is also mounted a gear wheel that controls the potentiometer for remote signaling of the position of the stretch weight. The device is enclosed in a housing. The operating command of the device is given by opening the oil circuit to the tank, which allows the counterweight to lower by pulling the cylinder piston. When the counterweight encounters the limestone in the oven, the device stops rotating and the potentiometer indicates at a distance the level of the stone in the basin. Weight lifting is done by means of the hydraulic cylinder which brings the feeler to the resting position.

The flue gases give off the heat of the limestone from the furnace, facilitating the start of decarbonation.

After the inversion, a tank that was in the combustion period enters the first regeneration period. During this period the flap air flap is open to the flue and closed to the combustion air pipe.

During the next inversion, the limestone is loaded into the tank. The feeding is done in weighed batches. The feed hopper being provided with three discharge valves, feeds successively the three ovens tanks. It feeds a tank that enters the second regeneration period.

Lime extraction is performed throughout the operation (both during the combustion period and in the two regeneration periods) with the help of the extraction tables whose operation is controlled so that at the expiration of each loading cycle the level of the limestone is lowered exactly in the existing position before the previous upload.

The lime extracted from the tables falls through the outlet funnels in three bunkers with flaps (locks). Through the locks the lime reaches the common reception bunker, from where it is evacuated with a vibrating extractor on a conveyor belt that unloads it in an elevator with buckets on the chain. It is taken from a conveyor belt and stored in one of the storage silos[6].

The temperature of the extracted lime should be between $60-100^{\circ} \mathrm{C}$. If the temperature rises, the flow of the cooling air is increased and if it decreases, the flow of the cooling air is reduced.

The obtained lime is stored in storage silos, the quantity of lime obtained is determined by silo measurements, by stock differences and by taking into account the density of the obtained lime.

Lime is used both for the production of lime assortments in its own production sections, but can also be delivered as such directly to the beneficiary.

\section{4 ) Technological process for obtaining lumps lime with granulation (20-50) $\mathrm{mm}$}

Obtaining the lumps lime with a predetermined granulation is done in a crushing-sorting plant composed of: conveyors with tape; crusher; screen; storage bunker.

Lumps lime extracted by free fall from the storage silo, is taken over by a conveyor belt and discharged into a jaw crusher. Under the crusher the lime is taken over by a conveyor belt and through a drainage trough falls on a vibrating screen, operated by an electric motor. The end is discharged on a conveyor with a strip located below the sieve and follows the flow of lumps lime extracted from the vertical ovens being stored in the silos used for grinding. From the sieve the refuse is taken through a gutter in a bucket elevator that transports it to the metal silo. For the delivery of sorted lime, under the silo is located a conveyor with rubber band from which the lime falls in the means of car transport.

The finished products obtained are: lumps lime; hydrated lime; ground lime for BCA[6].

\section{Protection of the air, water, soil and phonic quality}

3.1Protection of air quality [13]

- Sources and causes of air pollution:

- Technological process of obtaining the lumps lime - limestone calcination; 
- The technological process of obtaining the ground lime;

- The technological process for obtaining granulated lime;

- The technological process of obtaining hydrated lime;

- Hydrated lime bag installation;

- Granulated lime silos;

- Hydrated lime silage;

- The technological process of obtaining the lumps lime at the Maerz [1]oven;

- The technological process of obtaining the lumps lime with the dimensions between (20-50) $\mathrm{mm}$ at the sorting crushing plant;

- The technological process of transport and storage of lumps lime in silos.

The potential cause of pollution would be the anormal operation of the electrofilters.

To prevent pollution, containment, depollution and dispersion equipment such as[9]: Donaldson bag filter DLM C 2/7/15; bag filter Independenta Sibiu, filter Donaldson SA C 100; Donaldson Siloair VS 21 filter; Donaldson CPC12 dust collector; Donaldson VS 28 filter; filter with Luehr jet pulse bags, 60 filter bags; 2 Donaldson DLM V 18/15 filter; Donaldson CPC filter 8; CimZeropol 1000/20 Hydrator filter; Jet-Puls filter (ICT); Donaldson DLM V 60/15 filter; Donaldson DLM filter C 2/3/15.

The indicators are monitored with the following devices: TESTO $300 \mathrm{M}$ [2] exhaust gas determination device; permanent analyzer at Maerz [1] oven basket.

Air emissions are emitted by: powders, $\mathrm{CO}, \mathrm{NO}_{\mathrm{x}}$ and $\mathrm{SO}_{2}$ whose values must be permanently monitored so that they remain below the maximum permissible limits[4]. For example, table 1 shows the concentrations recorded for the dust emissions from the sources of pollution from a lime factory. From the measured values it can be observed that they are below the maximum allowed limit, which means a limitation of the impact exerted on the environment and a good management of the pollutants released into the atmosphere [7].

Table 1. Variation of powder concentrations

\begin{tabular}{|c|c|c|c|c|c|c|}
\hline \multirow{2}{*}{$\begin{array}{l}\text { Parameter } \\
\text { name }\end{array}$} & \multirow[b]{2}{*}{ Generating sources } & \multicolumn{3}{|c|}{ Concentrations } & \multirow{2}{*}{$\begin{array}{l}\text { Value CMA } \\
\text { and the legal } \\
\text { basis } \\
{\left[\mathrm{mg} / \mathrm{Nm}^{3}\right]}\end{array}$} & \multirow{2}{*}{$\begin{array}{l}\text { Amounts } \\
\text { [t/an] }\end{array}$} \\
\hline & & $\begin{array}{l}\operatorname{minimum} \\
{\left[\mathrm{mg} / \mathrm{Nm}^{3}\right]}\end{array}$ & $\begin{array}{l}\text { average } \\
{\left[\mathrm{mg} / \mathrm{Nm}^{3}\right]}\end{array}$ & $\begin{array}{l}\operatorname{maximum} \\
{\left[\mathrm{mg} / \mathrm{Nm}^{3}\right]}\end{array}$ & & \\
\hline Powder & $\begin{array}{l}\text { Exhaust basket filter mill } 2 \text { with } \\
\text { lime balls }\end{array}$ & 4,25 & 2,7 & 8 & 10 & 0,208 \\
\hline Powder & $\begin{array}{l}\text { Exhaust filter silo granulated } \\
\text { lime filter } 2\end{array}$ & 7,36 & 6 & 9 & 10 & 0,037 \\
\hline Powder & Cart filter silo, grinding lime 2 & 4,60 & 2,8 & 7 & 10 & 0,017 \\
\hline Powder & $\begin{array}{l}\text { Crusher filter drain basket } 10, \\
\text { with hammers }\end{array}$ & 6,29 & 3 & 8 & 10 & 0,037 \\
\hline Powder & $\begin{array}{l}\text { Crusher filter evacuation basket } \\
\text { with minced lime jaws }\end{array}$ & 4,27 & 2,6 & 8 & 10 & 0,018 \\
\hline Powder & Bulk lime filter sorter cart & 4,24 & 2,7 & 5 & 10 & 0,019 \\
\hline Powder & $\begin{array}{l}\text { Exhaust basket filter sieve sort } \\
\text { limestone stone }\end{array}$ & 3,75 & 2,8 & 5 & 10 & 0,022 \\
\hline Powder & $\begin{array}{l}\text { Exhaust filter discharge filter } \\
\text { limestone band }\end{array}$ & 3,34 & 2,1 & 5 & 10 & 0,005 \\
\hline Powder & \multirow[t]{4}{*}{ Maerz oven filter outlet } & 6,03 & 0,24 & 9 & 10 & 0,972 \\
\hline $\mathrm{CO}$ & & 5,46 & 0,78 & 20 & 500 & 0,88 \\
\hline $\mathrm{NO}_{\mathrm{x}}$ & & 40,74 & 27 & 72 & 100 & 6,57 \\
\hline $\mathrm{SO}_{2}$ & & 0.00 & 0 & 0 & 50 & 0 \\
\hline Powder & $\begin{array}{l}\text { Exhaust filter storage tank } \\
\text { lumps lime floor } 2\end{array}$ & 3,60 & 2 & 6 & 10 & 0,007 \\
\hline
\end{tabular}




\subsection{Water quality}

The technological water is used for the manufacture of hydrated lime and is used in excess of the amount of stoichiometric water needed[11]. The technological water is also used to cool the mill bearings, it is recirculated being used in the product by pumping and introducing it into the hydrator.

These are pre-treated in different decanters and separated, then through pipelines and collecting channels to the treatment plant.

Technical and technological installations for the collection (collection) of pre-treatment and water treatment:

- collection / decanting basin for the waters from the administrative pavilion;

- decanter - separator for the water from the workers' changing rooms;

- separate wastewater collection basin from the laboratory;

-wastewater treatment plant;

- the rainwater from the platform is taken through a network of streams and pipes, collected in a decanter where decanting / separation takes place.

After settling, both domestic and stormwater reach the sewerage network at the edge of the industrial platform.

The water samples for analysis are collected from the last house before the discharge into the channel.

\subsection{Soil quality protection}

For the protection of the soil[12], the diethylene glycol tank is provided with a concrete retention tank, to prevent any leakage of the product; there is a rainwater collection system, a system for collecting any accidental leaks and the fuel storage tank is located on the concrete platform and is provided with a retention tank.

\subsection{Sound protection}

- sources and causes that generate noise;

- compressors, conveyor belts, mills for milling, road traffic, blowers for the Maerz oven;

- measures, means and equipment for noise protection;

- the mills for milling are placed in closed enclosures, the hall for the milled lime being constructed from soundproofing panels that attenuate the dispersion of noise in the surroundings;

- housing of conveyors with belts, with soundproofing panels in the falling part of the limestone;

-the casing of the sieve for the limestone used in the Maerz oven with soundproofing panels;

- casing the double limestone bunker compartmentalized with soundproofing panels;

- housing of the upper part of the Maerz[1] furnace (limestone loading area) with soundproofing panels;

- lining the ceiling of the blower room with soundproofing panels and lining each blower separately with sound-absorbing panels;

- soundproofing walls are built that are meant to protect the neighbors of the site from the noise produced by motor vehicles traveling on the industrial road, which makes the connection between the site and the quarry.

\section{Measures to reduce pollution and to supervision of pollutant emissions results from the lime industry}

Of the recommended techniques for controlling emissions from the lime industry, the most important are:

- techniques for controlling NOx emissions[4]. NOx emissions depend on the quality of the lime produced and the shape of the oven;

- techniques for controlling $\mathrm{SO}_{2}$ emissions. $\mathrm{SO}_{2}$ emissions especially from rotary kilns depend on the sulfur content of the fuel, the shape of the furnace and the sulfur content required by the lime 
produced. Selecting low sulfur fuels can therefore limit $\mathrm{SO}_{2}$ emissions as well as lime production with higher sulfur content[7];

- techniques for controlling dust emissions[11]. Rotary ovens are generally equipped with electrostatic precipitators due to the relatively high exhaust gas temperatures. They are used at temperatures above $370-400^{\circ} \mathrm{C}$. Electrostatic precipitators can influence the amount of dust by bringing it below $50 \mathrm{mg} /$ $\mathrm{Nm}^{3}$. A rotary lime kiln fitted with an electrostatic precipitator reaches below $20 \mathrm{mg}$ dust $/ \mathrm{m}^{3}$ in normal operation.

Synthetic filters are also used, especially in preheated ovens where the exhaust gas temperatures are lower. Synthetic filters generally operate at temperatures above $180-200^{\circ} \mathrm{C}$ and can reduce dust concentrations to less than $50 \mathrm{mg} / \mathrm{Nm}^{3}$. In some cases, even $5 \mathrm{mg}$ of powder $/ \mathrm{m}^{3}$ can be reached daily with synthetic filters, but in this case the devices should be changed 1-3 times a year. The level of long-term performance of synthetic filters depends on the maintenance of the filter and how often the devices are changed. Emissions levels can be low, but costly.

The measures for monitoring the emissions generated by the technological processes for the manufacture of lime consist of monitoring the quality indicators of the wastewater discharged and the control of the emissions of pollutants into the atmosphere, which must be carried out periodically through specialized laboratories. Thus, it is necessary for water: monitoring of final effluents by analyzing quality indicators such as: $\mathrm{pH}$, suspended matter, $\mathrm{CCO}-\mathrm{Cr}$, extractable substances with organic solvents, sulphates, carbonates. For air, it is necessary to monitor the emissions of combustion gases: CO, NOx, SOx and powders - at the level of limestone calcining furnaces, monitoring the emission of powders - at the level of dust systems. For the soil, it is necessary to monitor the soil in the enclosure, in the green areas, in the vicinity of the limestone silo, as well as in the vicinity of the fuel depot, the indicators to be followed are: $\mathrm{pH}$, organic carbon, petroleum product, sulphates, carbonates. The results of the monitoring performed highlight the impact on the environmental factors air, soil and water, so that the areas adjacent to the industrial platforms carrying out lime activities are not affected [12].

\section{Conclusion}

The technological processes in the lime industry are generating emissions of pollutants into water, through wastewater and stormwater, emissions of atmospheric emissions, namely, flue gases: NOx, $\mathrm{SO}_{2}, \mathrm{CO}$, VOC, powders, as well. and different types of waste that can affect soil quality.

Emissions depend on the shape of the furnace, the operating conditions, the fuel used and the quality of the lime stone.

Gaseous pollutants from the lime industry, as well as powders, may act differently, by their effects on each individual, depending on their quality and concentration.

The main compounds or elements that can be found in the soil of the industrial lime producing area are due to the atmospheric emissions, the loss of raw materials during handling (in waste water, soil and basement) and the improper storage of the resulting waste.

There is also a potential risk of contamination of surface and groundwater as a result of insufficiently purified alkaline wastewater, with a high content of suspended matter and extractable substances.

In order to reduce the impact of noise and vibration sources on the environment, the appropriate measures must be taken to place the technological installations in tight spaces, which cushion their activities, the installation of soundproofing panels, and the housing of the conveyor belts.

Thus, it can be concluded that, in order to comply with the obligations and conditions imposed by the regulatory acts regarding the quantitative and qualitative management of the waters, the sustainable use of the resources, the protection of the environmental factors and the health of the population, the industrial units in which there are technological processes for manufacturing the water.

The lime must have means of treatment for waste water, filters for the retention of powders from the gases emitted into the atmosphere, soundproofing for the premises where ball mills operate and for other machines that produce noise. 


\section{References}

[1]. Becherescu, D., Thaler, M. - Cuptoare şi utilaje în industria varului, Ed. Didactică şi Pegagogică, Bucureşti, 1973;

[2]. Chiriac, V., Ene, Gh. - Utilaje mecanice din industria materialelor de construcţii, Ed. Tehnică, Bucureşti, 1979;

[3]. Dascălu, V. - Compoziţie, procedee şi produse noi în construcţii, Ed. Tehnică, Bucureşti, 2002;

[4]. Davidescu, V. ş.a. - Poluarea mediului. Surse - Combatere, Ed. IAMB, Bucureşti, 1992;

[5]. Ianov, I., Voica, N., I. - Materiale de construcţii pentru instalaţii, Ed. Didactică şi Pedagogică, Bucureşti, 1975;

[6]. Lazăr, N. - Materiale de construcţii, Ed. Ceres, Bucureşti, 1987;

[7]. Negulescu, M., Ianculescu, S. - Protecţia mediului înconjurător, Ed. Tehnică, Bucureşti, 1995;

[8]. Nicolăescu, N., Drăghicescu, C. - Materiale de construcţii, Ed. Didactică şi Pedagogică, Bucureşti, 1974;

[9]. Opriş, S. - Manualul inginerului din industria varului, Ed. Tehnică, București, 1980;

[10]. Rainu, A. - Industria varului, Ed. Didactică şi Pedagogică, Bucureşti, 1976;

[11]. Rojanschi, V. - Ingineria şi Protecţia Mediului, Ed. Economică, Bucureşti, 1997;

[12].Tomescu, I., Racoceanu, C., Hristov, E. - Factori de risc antropici, Ed. Academica Brâncuşi, Târgu-Jiu, 2003;

[13].Tumanov, S. - Calitatea aerului - Ed. Tehnică, Bucureşti, 1989 